Julita Orzelska*

ORCID: 0000-0002-2539-1736

Szczecin, Poland

\title{
Saving Humanity: Despair and Death as Pedagogical Challenges while Caring about Human Existence
}

\section{Ocalić czlowieczeństwo. Rozpacz i śmierć jako wyzwania pedagogiczne $w$ trosce o jakość egzystencji człowieka}

\begin{abstract}
The concepts analysed in this paper pertain to despair and death, since these are insufficiently present in pedagogical narrations. Despair and death, which accompany our existential experience throughout our lives, are most frequently treated one-sidedly, pejoratively, and presented as an expression of human evil. The thoughts of Paul Tillich, Viktor Frankl, Vittorino Andreoli and Krystian Lupa open a space for understanding despair and death as existential challenges a person needs to be capable of facing and should treat as valuable experience; an experience which creates an opportunity for a new dimension in our own appreciation of life. For this reason, an existentially oriented education seems to enable serious thought about a person in the context of their entire life.
\end{abstract}

* Dr hab. Julita Orzelska, Associate Professor, Institute of Pedagogy, University of Szczecin, email: julita.orzelska@usz.edu.pl. 
Keywords: existentially valid education; 'the will of sense'; despair and death as valuable existential experience; 'working through' despair to care about quality of life; a person's concern with protecting their fate; existential insecurity.

Abstrakt: Kategorie, które stanowią przedmiot analizy, dotyczą rozpaczy i śmierci, w niewystarczający sposób obecnych w narracjach pedagogicznych. Rozpacz i śmierć, które towarzyszą doświadczeniom egzystencjalnym na przestrzeni całego życia, najczęściej traktowane są jednostronnie, pejoratywnie, ukazywane jako doświadczanie zła ludzkiego. (Od)czytanie myśli Paula Tillicha, Viktora Frankla, Vittorino Andreoliego czy Krystiana Lupy otwiera przestrzeń rozumienia rozpaczy i śmierci jako wyzwań egzystencjalnych, z którymi człowiek nie tylko musi umieć się mierzyć, ale które powinien traktować jako wartościowe przeżycie dające szansę na nową jakość własnej troski o życie. Dlatego edukacja zorientowana egzystencjalnie wydaje się być wyznacznikiem poważnego myślenia o człowieku w perspektywie całożyciowej.

Słowa kluczowe: edukacja istotna egzystencjalnie; „wola sensu”; rozpacz i śmierć jako wartościowe doświadczenia egzystencji; „,przepracowanie” rozpaczy w trosce o jakość życia; troska o człowieka w ochronie jego losu; (za)gubienie egzystencjalne.

\section{Introduction}

The process of becoming a person, which is based on various extreme states of experiencing, defines human existence; it creates a space for caring about oneself, and includes a number of traumatic, damaging occurrences, mixed with optimally positive ones (which can also be called 'happy moments'). Although positive occurrences provide evidence of a highly energetic state of functioning, they are insufficient to create a 'complete' human existence. Therefore, the concepts which are the main focus of this analysis are despair and death, or two topics which in my opinion are insufficiently present in pedagogic narrations. These concepts are capable of promoting the revitalisation of a person's life energy and restoration of their spiritual potential.

When desires, aspirations and visions gradually die out, and a man becomes spiritually dead, incapable of meeting further challenges, and lacking any motivation to live, despair and death become part of the final phase of a human life, where they certainly dominate as painful existential references. The case of premature, slow 'acts of dying' is described by Jan Szcze- 
pański (1988, pp. 301-302) as a person 'reducing their actions, withdrawing from the activity, giving in to exhaustion and discouragement'. Very often despair and death accompany existential experiences throughout our entire life, released by phenomena we are not able to cope with; such as when we encounter them personally, and when we attempt to help others, or contemplate their presence in the conscience of a person we consider important to us. This creates a space for difficult dilemmas pertaining to our fate and experiences, in the face of which we are helpless, and unable to cope with or react to them - unless, as suggested by Erikson, we attempt to use them, and work through them to restore our existential condition. Working through despair may determine our choice of a life path, our discovery of another behavioural philosophy that contributes to our fulfilment, and our ability to confront suffering and grief; yet it may also make us give in to feeling lost, doubtful, or simply self-destructive.

The clear gap in pedagogical thinking, in terms of insufficient consideration of the idea of despair, results most probably from a single-sided, pejorative perception of despair as a human evil one should be protected against in order to survive. Since this single-sided perception of despair is in line with common beliefs, the evident complexity of the issue suggests the need for more in-depth analysis. According to Paul Tillich (2004, p. 75),

The pain of despair is the agony of being responsible for the loss of the meaning of one's existence and of being unable to recover it. One is shut up in one's self and in the conflict with one's self. One cannot escape, because one cannot escape from one's self. ... There is a suicidal tendency in life generally, the longing for the rest without conflict. ... Second, in every moment of intolerable, insuperable and meaningless pain there is the desire to escape the pain by getting rid of one's self. Third, the situation of despair is most conspicuously a situation in which the desire to get rid of one's self is provoked and the image of suicide appears in a most tempting way. Fourth, there are situations in which the unconscious will to live is undermined and a psychological suicide takes place, in terms of non-resistance to threatening annihilation.

Furthermore, the theologian (Tillich, 2004, pp. 73-74) states that

The destructive character of existential insecurity and doubt is manifested in the way man tries to escape despair. He tries to make absolute a finite security or a finite certainty. The threat of a breakdown leads to the establishment of de- 
fences, some of which are brutal, some fanatical, some dishonest, and all are insufficient and destructive; for there is no security and certainty within finitude.

Pedagogical reflections from the analysis of the above quotation push us to consider how we develop the ability of 'working through' despair. On the one hand, this ability is entangled with the escape strategy from a situation where the pain outweighs the will to fight; and on the other, it relates to the motivation to carry the weight of life while being aware of the meaning of recovered values we have been previously unaware of - for instance, enriching the quality of one's existence. In the context of this analysis, the comment made by Józef Tischner provides a reason for reinterpreting and seriously considering the issue of despair:

Despair is the basic 'fracture of soul', when something is locked and trapped within the horizon of evil, touching the core of who one is. Despair is a chosen state. It does not get to a man without his acquiescence. While living the curse, a man agrees to a life in despair (Walczak, 2007, p. 127).

The comment linking despair with our choice of acquiescence to existence and domination opens a space for a number of questions; these are important for human existence, and pertain to confrontation and 'using' the pain of despair in the process of building oneself. Therefore, it is not about coping with despair in order to survive; rather, despair can be 'rebuilt' to strengthen oneself. Hence, the despair is an opportunity for a valuable experience, and not just a damaging, negative one: this is an important pedagogic message. This approach is close to that of Jan Szczepański (1988, pp. 17-20), who stresses that we can overcome despair by creating new values, which process the pain and give the despair some sense in our existence. The extraction of potentiality from experienced suffering indeed strengthens the human and gives us energising power when we finally face the collapse of temporal existence, and reach existential despair. The ability to convert this despair into triumph provides a special opportunity for choosing to be unique in exceptionally difficult life circumstances. Szczepański argues that without experiencing despair, one cannot appreciate happiness. In his insightful poem The Ode to Despair Jan Twardowski (1979) contradicted the stereotypical approach to despair by praising this state, which usually has a negative association. The title itself makes us reflect, since the author undermines the thoughtless and unjust attitude which negates despair and states that it is inappropriate to try to escape from it ('saints escape from it like from cholera'), 
or fight with it ('moralists try to trip it and ascetics kick it'), or approach with helplessness ('doctors prescribe drugs to eradicate it'). While defending despair ('poor despair'), he tries to convince us that the common attitude to it is detrimental ('they call you a sin'), and formulates an important pedagogical message - namely, that while developing as a person one should be able to learn from extreme experiences ${ }^{1}$ (joy and sadness, happiness and despair), since this diversity strengthens existence and makes it complete. Undoubtedly, Jan Twardowski (1979) justifies the value of existential despair:

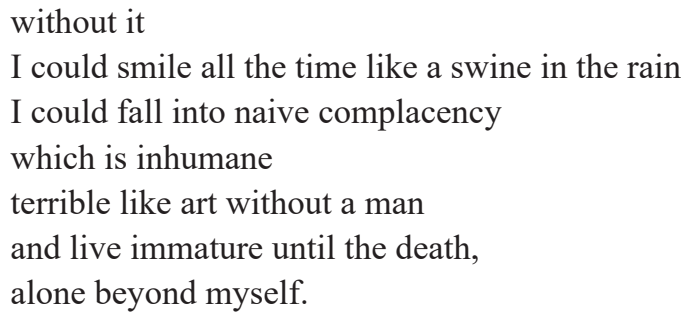

Despair enables us to appreciate usually neglected aspects of our experiences and behaviours, and discover the undiscovered elements of life, which are evidence of the complexity of human existence. Here, every experience even the most traumatic - may reveal the meaning of life, provided that we seriously and wisely examine its existence in our life. It also happens, as described by Tadeusz Frąckowiak (2007, p. 70), that 'sometimes our fate brings sudden experiences, depriving us of our dreams and devastating the space of our existence.' Then, following the reasoning of Jan Twardowski, while refraining from squandering a chance for reflecting on the 'benefits' from difficult experiences, we should attempt to 'learn the lesson of pain' in the context of our (and not only our own) further life. By using simple words, Jan Twardowski names what we often fail to include in our pedagogical activity. Additionally, when analysing existential experience, Phil Bosmans (1991, p. 43) writes: 'Why should we remain silent about death? / We can learn from it how to live / calm and satisfactory life.' It is also worth remembering the hope expressed by John Paul II in his last will: he wrote that death may turn out to be 'useful.' Undoubtedly, he was reflecting on what his life would contribute to the contemporary world after it had come to an end.

1 Jan Twardowski (1993, s. 159) pointed to the bipolarity of existence resulting from the natural rhythm. In his poem Together, he writes: 'Hope and despair / Joy and pain / ... / Like two hedgehogs bewildered by one another / They look together for a place for themselves.' 
Most frequently, we try to eliminate despair, since it is treated as a clear existential obstacle in various phases of our development. This to some extent conflicts with the postulate of the 'meaning of life' in old age, which respects the value and right to despair, as evidence of the potential vitality of our memory and the capability of expressing our experience. No one can deny that despair has its extreme one-sided destructive form, which is revealed through regression or even acts of suicide. According to Tillich (2004, pp. 70-72), the source of immense suffering that blocks the self-preservation instinct, which pushes us to 'harness' this overwhelming despair, is 'existential estrangement,' where a person left on their own in solitude is incapable of overcoming self-destruction. Therefore, self-destruction cuts off the suffering we try to defeat, and in which we try to find some meaning. For this reason, while learning how to work through despair, while at the same time learning how to 'read' despair in various relations (not only educational ones), and how to react to the despair ${ }^{2}$ we see in others, we may offer oth-

2 Despair, which intruded on the existence of a man, 'has painted' its image on his face; a face which more or less is perceived by others. Józef Tischner in his Philosophy of Drama (2012, p. 82) rightly notices that in a tragic situation, our face 'reveals affliction, our disagreement with the fact that life is not present.' Therefore, the ability to remain mindful in the relationship with another person seems to be a major pedagogical requirement, regarding the discovery of truth about a person and provision of assistance in living through a tragedy in a sense of discovering a new truth of life, which is useful in optimising our potential and life energy. We should hear the cry of despair, face it with our pain and that of others - it is a test of humanity that we should undergo while making our choices. The idea of an existence which 'brings a man to life' when suffering, grief and death are present in his life, is called the 'philosophy of gift.' Tadeusz Frąckowiak (2007, pp. 68-73) writes that it should be a basis for educational activity. On this occasion, it is worth mentioning that from the reverse perspective, frequent causes of existential despair, as described by Józef Tischner (2012, pp. 74-79), are masks people wear to meet social expectations placed upon them. Paraphrasing Thomas Merton (2005), we can add that 'while creating a mask of apparent unity' with others, we are led to suffering and despair, which deafen our internal decisions that are 'in a sense in blanco check and promise.' Following the reasoning of the renowned friar, we may risk a statement that despair can be this type of a promise of discovering important life truths for oneself, while assuming that a person can face despair and admit it exists, and instead of treating it as evil and 'complaining and relishing its sleaze.' To meet despair means 'refraining from creating theories of suffering, being a martyr, refraining from calculating the cost of courage to face despair, refraining from discarding help, but instead humbly accepting it and drawing conclusions and building on it a new covenant for oneself' (Merton, 2005). Sometimes a person puts on a mask when trying to hide their dramatic experience. This leads to suffering and despair, but does not prevent the person from resorting to the affirmation of life, while taking into account the source of despair and accepting despair itself. Although the author of the analysis does not 
ers assistance in dealing with that existential obstacle. This issue defines the direction of our educational project, providing a space for reflection on the meaning of our education.

Tillich wrote $(2004$, p. 71$)$ :

It is possible to speak about the type of suffering in which meaning can be experienced, in contrast, for example, to meaningless suffering. Suffering is meaningful to the extent that it calls for protection and healing in the being which is attacked by pain. It can show the limits and potentialities of a living being. Whether it does so or not is dependent both on the objective character of suffering and on the way in which it is experienced by the suffering subject. There are forms of suffering which destroy the possibility of the subject's acting as subject, as in cases of psychotic destruction, dehumanising internal conditions, or dramatic reduction of bodily resistance.

This raises the crucial pedagogical and psychological issue of how, instead of eliminating despair, we can optimise it in the structure of existential tensions. Indeed, the restoration of harmony - in opposition to experiencing despair - may lead to the inability to see the inalienable tension of emotions and knowledge in our life memory about the fate of an individual, and we thus become destined to the said 'inhumane smile.' As Erikson reminded us, it is easy to be free from despair in the case of someone who has lost their memory and lives with confabulations. Therefore, the lack of despair does not automatically translate into enhanced vitality and 'practical wisdom,' as postulated in the model of the life cycle.

The consideration of despair and death highlights important existential aspects, treated as residual components of human experience, while addressing how to cope with the various situations and challenges they bring. I should note, however, that a serious intellectual and ethical approach to death in pedagogy is possible, provided that we deal with a series of difficulties and remain open to paradoxes. This means, in particular, that it is necessary to deviate from common beliefs and desires which dominate in typical non-reflective and immature attitudes. One such attitude treats the experience of despair or death as a curse, disturbing the harmony of life and contradict-

attempt to dwell on seeking and revealing the unconscious truth about oneself, in the context of the reinterpretation of despair, the issue of 'putting on masks' seems to be important, and thus it is worth highlighting its existential consequences. 
ing, instead of completing, its existential meaning. This paper highlights the significance of programming possible pedagogical activity which recognises despair and death as existential challenges, whereby we need to be able to provide our support and help others to get through the experience. First and foremost, we should consider our attitude to despair and death, and how it can influence the quality of care for our life and that of others. The main aim is to use this opportunity to face a phenomenon which is so deeply embedded in the human condition.

\section{Caring about the meaning of life as a strategy for coping with despair, as viewed by Viktor Frankl}

In the contemporary period, despair - as described by Frankl (2010, p. 214) - is more than ever an essential global problem. In the consumption society, continuously generated new needs, along with the ever-stronger desire to meet them immediately and without questioning them, are emphasised more than considering of the meaning of life, or reflecting on the existence of man and humanity in the face of apparent norms and illusive meanings. Questions about what strengthens a man in ever-changing and difficult circumstances are replaced with continuous activity dictated by social expectation, and concentration on apparent gestures. Participating in the 'race' for what cannot be fulfilled effectively prevents a person from any contemplation of their own existence, in terms of its meaning. This imposes an order on the person's activity: as Frankl puts it, it energises them not only when they are calm and happy, but primarily in traumatic situations when previous temporal existence is interrupted and existential despair appears. It is easier for a person to find that meaning during suffering and despair, when the direction of their previous existence sets that meaning, and more difficult when reflection on the meaning is marginalised and disregarded. 'Shortage of energy may appear anytime, but meaning can never be missing from human life' (Frankl, 2010, p. 215); this is because 'life makes sense in every circumstance, even the most inhumane' (Frankl, 2014, p. 16), or when we are not aware of it. Hence,

there is no such situation which is truly without meaning, ... and apparently negative sides of human existence, in particular the tragic triad, comprising suffering, guilt and death, can be transformed into something positive, or success, provided we adopt a relevant attitude and mindset (Frankl, 1971, p. 129). 
Frankl has drawn attention to the fact that despair appears too often and too easily when a person, especially if they are young, is not prepared to cope with the sense of their suffering. Then, a special type of existential despair comes into play. It has a tiered structure, with meta-despair above the accumulated source of despair that is directly linked with specific experiences. This was described in the famous logotherapist's transcription of his conversation with a twenty-five-year-old patient, who had an anxiety disorder and despair related to it. Frankl said: 'you should not despair because of your despair, but rather you should consider it to be a proof of something that I call "the will to meaning"" (Frankl, 2010, p. 126). It is not a coincidence that Frankl emphasises his intention to help others discover, through conversation, the sense of suffering, or even devotion, as a precondition to cope with despair as an inability to meet the challenge. For this reason, it is important to overcome the sense of temporality and the conviction that life no longer has anything to offer; instead, we should treat suffering and despair as an opportunity and a new challenge which can be transformed into a triumph, instead of living from hand to mouth. If we do not try to find meaning in suffering and despair while looking to the future, 'we resign from fighting for ourselves and fall into mental and physical ruin' (Frankl, 2014, p. 121).

Finally, life boils down to taking responsibility for oneself to find an appropriate solution to problems and tasks we face. Those tasks, and consequently the meaning of life, are different for various people and situations. Therefore, it is not possible to provide a general definition of the meaning of life. Questions about the meaning of life cannot be responded to with general answers. 'Life' is not a blurred concept, but a very true and specific reality, similarly to life tasks which are something very real and specific. ... No man and his fate can be compared with other people and other fates. ... A man needs to accept that in his suffering he remains someone unique, a lone being in the universe. No one can provide a relief, and no one can suffer for him. However, he has a unique chance of choosing the manner in which he carries the burden (Frankl, 2014, pp. 125-126).

It is also important to notice that Frankl states that not everyone is capable of facing despair; especially for those who want to help others, in the role of a specialist. Therefore, he warns that 'one needs to face his own existential despair, to be able to immunise his patients against it' (2010, p. 178). He can then assist his patients in the process of discovering meaning and value; he refers to this logotherapeutic procedure as the 'common denominator technique' (2010, p. 156). 
Nevertheless, among the paradoxes of despair one should not neglect, Frankl points to the 'phenomenon of despair despite success,' when we encounter 'existential emptiness,' which a person finds hard to cope with on their own. Thus, a measurable success, or a series of successes at the professional level, may become a source of existential loss, leading to an 'emotional crisis.' According to the logotherapist, the 'inner emptiness' that triggers despair is caused by, inter alia, hyper-reflecting, or excessive concentration on the goal we would like to achieve, rather than its sense as an imperative whose recognition determines specific actions. Therefore, the goal alone is not the source of human activity (paradoxically, meeting the goal may not guarantee satisfaction and fulfilment, but lead to despair due to emptiness, since the task has been completed and no further prospects are established). It is the meaning of activity that contributes to fulfilment of the tasks completed, and it does not focus human existence on the completion of a task only. Frankl wrote (2010, p. 133): 'any spontaneity and activity can be paralysed if we excessively focus on them.' Success or happiness cannot be goals in themselves. If they are treated as tasks, it contradicts the idea of them having meaning, as referred to by Frankl. At the same time, it prevents us from realising a need which is a source of our (hyper)activity.

Don't aim at success - the more you aim at it and make it a target, the more you are going to miss it. For success, like happiness, cannot be pursued; it must ensue, and it only does so as the unintended side-effect of one's dedication to a cause greater than oneself ... Happiness must happen, and the same holds for success: you have to let it happen by not caring about it (Frankl, 2014, p. 17).

Our hyperactivity, which imposes the implementation of consecutive tasks, is in fact an attempt to escape from the emotional emptiness; it is thus an inner activity - as described by Frankl - instead of confrontation with oneself in solitude. Therefore, Frankl mentioned that a 'man needs to have the courage to be alone' $\left(2014\right.$, p. 129) ${ }^{3}$ in order to be fully aware of his responsibility. Furthermore, one needs to help him, since this is the basis of a creative attitude, counterbalancing the typical oscillation 'between professional hyperactivity' on the one hand, and prevailing self-defence mechanisms on

3 Paul Tillich (2004, pp. 70-75) also writes about the ability of 'remaining in solitude' or 'having solitude,' and the ability to experience one's own genuineness, which counteracts existential alienation, emptiness and dealing with despair. 
the other. This attitude apparently provides us with spiritual rest, or 'escape from oneself,' and this helps us to avoid facing our inner emptiness.

\section{Syndromes of despair in educational relations (among others) by Vittorino Andreoli}

Vittorino Andreoli, a distinguished Italian psychiatrist, devoted much space in his publications to various dimensions of suffering, fear and existential despair. His work, filled with a humanist concern for true empathy and accompanying people in pain, is the voice of the majority who treat suffering as a major problem of contemporary society. If we fail to notice suffering at the right moment and do not 'overcome' it with a new life strategy, we will be destined for emptiness and despair. We need to be able to recognise syndromes of despair, and accordingly educate people so that their suffering and despair do not squander their potential for a valuable existence.

While discussing the syndromes of childhood suffering, Andreoli (2009, pp. 127-137) stressed the following:

1. Misunderstood child syndrome refers to misunderstood or ignored children. A child suffers due to the lack of understanding from other people, falling into despair because of helplessness that causes emotional emptiness;

2. Rejected child syndrome applies to a child who differs from others in a negative sense. Andreoli wrote that "when we distinguish between good and bad children, it means that the bad ones, in the case of intelligent and unintelligent, are the "unintelligent" ones, whereas between pretty and ugly, it is the latter' (2009, p. 129). Additionally, Andreoli did not mention that when distinguishing between poor and rich, the bad child belongs to the first group. In principle, we can agree with the author that a rejected child 'is in fact the victim of the society that creates rules according to which some individuals are excluded and others rewarded, instead of promoting the establishment of mutual aid groups in which everyone has a role to play and is treated with respect' $(2009$, p. 129).

3. Skilled child syndrome means that a child falls victim to their own skills, and to the entire education system, which excludes less skilled individuals. A child's suffering may result from rejection by others (the so-called less able children), as well as from the continuous pressure of requirements and expectations. Then, despair can be 
caused by any failure and the sense of disappointing others (parents and teachers). Contrary to some obvious stereotypes, being a genius promotes suffering, due to the inability to cope with one's above-average skills.

4. Television and computer game addict syndrome - this appears in children who spend the majority of their free time in front of their TV sets or computers, and abandon other leisure activities. Their engagement in the virtual world prevents the development of interpersonal relations, resulting in inadequate reactions, solitude, and ensuing suffering.

5. Beaten child syndrome applies to children 'who experienced beating as a constant element used by the child to measure the passage of time. Such a child yields to others without any resistance, which is a sign of low self-esteem' (2009, p. 131). The suffering and despair of a beaten child result from perceiving him/herself as an object, getting beaten, rejected and condemned. Being convinced that he/she is unimportant, the child always accepts the will of others, apologising for things he/she has not done. Being a victim of abuse, the child accepts suffering as the only form of relationship.

6. Prostituted child syndrome - Andreoli defines it using the term of a 'painful smile.' Such a situation may apply to a child chosen by a paedophile, and the child is deprived of true emotional relations in his/her everyday life (family, school). The same applies to many children who are forced into prostitution by their parents. In such a case, we can consider that suffering is a price paid for attracting a small amount of attention.

7. Coloured child syndrome refers to a minority of children with a different tone of skin to the one prevailing in a given location. Such discrimination triggers despair, which can be amplified by, for instance, living away from their home country, and encountering difficulties in settling into a new place.

8. Objectified child syndrome - this applies to a child who is brought up to meet the expectations of their parents, without taking into account the child's opinions and needs. Then, suffering ensures, due to being objectified, where a child may gain approval only with complete subordination to the norms, forms and duties imposed by frustrated adults. The lack of respect for child's individuality generates despair, which, paradoxically, is treated as being ungrateful. 
The suffering that results from each of the syndromes prevents the child from having a valuable existence, and he/she is rejected or neglected in educational relations. However, the tragic existence of a child can be changed, provided that those responsible for the child's upbringing are capable of recognising suffering and are willing to help, or to change the situation of the suffering child. This is achieved by reducing or eliminating existential obstacles, according to the principle of doing good for other people.

Sometimes our fate surprises us suddenly, depriving us of dreams and devastating nearly the entire space of our existence. Then, if deprived of the warmth of another person's hands, fulfilment gives in to being lost, and even the annihilation of a chance for humanity ... A mind itself is insufficient to be a brother to another person ... The only value of education is the good of another man ... (Frąckowiak, 2007, p. 70).

\section{Death as a challenge for art, and consideration of the meaning of existence, according to Krystian Lupa}

Krystian Lupa, theatre director and pedagogue, formulates an existentially important thesis that death is the only serious challenge for contemporary art, and that facing it in the artistic dimension gives the theatre a special role. For Lupa, death is a challenging subject; we may not always be strong enough to confront it, despite the fact that if it was not for death, people would not consider the meaning of life. 'The idea of death is something every conscious being needs to confront' (Lupa, 1999, p. 6). This is especially true because the core of the mature examination of death is the appreciation of death; we should treat it not as an obstacle we rebel against, but as something we care about while being aware of the finite.

'If it were not for death, we would not do anything. If it were not for death, humanity would fail to develop a dialogue with the world. Death is an exceptional pressure' (Gonet, 2002, p. 50). 'Death of an individual is necessary, otherwise there would be no creativity, culture, and human achievements' (Lupa 1999, p. 8).

Death may also be related to our initiation, which requires something to die symbolically, as a precondition for the new spiritual birth - 'new' being beyond the point of no return. In the description offered by Lupa, encountering, fascination with, and liberation from such a dramaturgy occurs in relation 
to a particular person; for Lupa it was the works of Tadeusz Kantor, whom the artist referred to as the 'master.'

I can call myself the disciple of Kantor since I was deeply fascinated by his theatre. ... And I can refer to a number of performances which started my mature life, as they were created while being enlightened by Kantor. ... Only now I know that it has been a natural way, a key to our own emotional truth. Kantor was such a key for me. Of course, a moment comes when you need to free yourself from it. ... I did not want to renounce Kantor ... However, the way he became distant was natural. ... Now, I rarely think about Kantor, but for certain he is still there in me (Lupa, 1999, pp. 24-26).

While referring to the work of Carl Gustav Jung, whom he also considered to be his 'spiritual master,' Krystian Lupa wrote about the symbolism of the spiritual meeting and a new perception of one's life path, with all its fascinations and hardships.

Long ago, Carl Gustav Jung became my spiritual master. I keep reading his book over and over again. In different periods of my life those books seem different, and every time I find something different in them. Jung is very special to me, like no one else. His understanding of the world, his vision and interpretation of human spirituality in the world - everything he said and wrote spoke to me in a very emphatic manner (Gonet, 2002, p. 117).

An opportunity for a meeting may help us continue along our journey, which is not free from dilemmas, tensions, being torn between identical or similar choices. Life - treated as a journey with experiences one needs to face - may facilitate the encountering of an artist's works that give the reader an insight into the artist's experience; this can help the reader at the beginning of his/her journey, through seeing him/herself in that artist as 'someone more mature after completing the journey' (Gonet, 2002, p. 117). It is a form of education which enables us to recognise how we might make decisions: without imposing any choices, this process teaches us thorough analysis of choices made by another person.

You are about to start a journey, you choose your way and meet someone who has made that journey, and you go across a bridge over the abyss with the help of a master. Once you find yourself on the other side, you can spread your wings 
and continue the journey yourself, spread or build your own route... There are many abysses on our way. (Gonet, 2002, p. 117)

In Lupa's publications we can find elements of a deadly threat from the challenge of the abyss, and it is hugely worthwhile to listen to someone who has had that experience before. This should help us to harness the situation, confront our own concerns and the experience of that other person, and gather our strength for the journey; or we may become convinced that it is worth overcoming our weaknesses and meeting challenges. In such an instance, someone's voice with its message can be a road sign on the map of our life. Lupa refers to thoughts that initiate new interpretations and experience, as described by Jung, or major disruption, as mentioned by Kantor; at other times, there may be a relief due to a long-awaited liberation, as in the relationship with one's father. This example was described by Lupa in quite a dramatic way: 'my father's death released me from pressure. The day of my father's death was when I felt I was a mature man. ... The pressure of the father-son relationship was immense' (Gonet, 2002, p. 127).

Lupa provides comments in the area of a special pedagogy of death; this is paradoxically understood as the artist's split from any pedagogy, as it is narrowly understood, and then treating death as one of experiences that cannot and should not be pushed away beyond our sight or understanding of the world:

... if a child does not learn about atrocities of this world from you, he/she will learn it from someone much more ruthless. If you do not tell your child about suffering, your friend will do it in a cruel manner. Parents, who excessively protect their child, in fact expose it to everything they have been trying to protect it against... Then, your child will be astonished by knowledge provided less aptly, more trivially, and drastically ... much more ruthlessly. (Gonet, 2002, p. 126)

In his description of a child's relationship with death, Lupa expressed concern for the sensitivity of education in its broad sense, since 'a certain kind of sensitivity can be described as morality rather than rules' (Gonet, 2002 , p. 136). It is important to prevent dos and don'ts becoming their opposite, since 'lies, formalities, formal or informal bans lead to the accumulation of unreleased energy' (Gonet, 2002, p. 133). Lupa emphasises that there are societies 'in which young generations are to a large extent free from limitations. Hence, they are much more independent, and there is no danger that 
people will start murdering each other' (Gonet, 2002, p. 133). Lupa shows elements of pedagogical awareness, indicating the need for a developed pedagogical reflection, diagnosis, and ongoing vigilance regarding issues that necessitate the pedagogy of partnership with one's child. The measure of this pedagogy is the responsibility that stems from caring about education, by using one's own influence to make a child resistant to other influences and capable of growing as an autonomous being. This leads to the ability to express resistance in various relations; such a resistance can help to avoid pathological influence, collapse, entanglement or unhealthy fascination, suffering, and death (not only the spiritual one).

The partnership is understood as 'deep contact with a child' (Gonet, 2002, p. 137), in which we observe a 'certain psychological process of intruding upon each other' (Gonet, 2002, p. 137). This process contradicts schematic behaviour, which 'takes advantage of the situation' (Gonet, 2002, p. 140) (including those painful ones); rather, it shapes the ability to deal with problems in our lives and protect ourselves against cruelty and existence traps.

The partnership cannot be based on codified rules or regulations. It is the process of struggle between two personalities, a process which requires effort to be made by each party. It is possible that a contact between a child and an adult is painful, but ... an attempt should be made quickly to develop the partnership.... If we do not initiate that process in early childhood, later we may not be able to initiate it ... Building a firewall, keeping certain concerns, doubts, depression or aggression, hardships, away from a child is a mistake. If parents use such a firewall and filters and when ... something suddenly breaks, it is a tragedy - a child is unprepared, terrified, shocked and disoriented. (Gonet, 2002, pp. 140-141)

Lupa (2003a, p. 218) provides existentially significant examples, which show his excellent responsiveness to suffering, despair and death. While describing despair and death-in other words, atrocities of human existence-he admits his sarcastic attitude to his pedagogues and university administration. He highlights the imperfection of pedagogy, and the shortage of existential competencies among pedagogues who are indifferent to existential challenges, which require awareness and an autonomous and creative attitude. It is hard to disagree his statement:

It is not important to come the next day with truth, but to appear transformed by a struggle. ... Perhaps not a system itself, but the attempt to create one, may 
become of value in this continuous process of recovery and downfall-known as creation. It is something that can replace a dead method... (2003b, p. 6).

\section{Conclusions}

The discussed examples highlight the need for an in-depth reflection on the life of a person entangled in difficult, worrying and extreme experiences; they test us not only due to their sudden nature, but primarily through the confrontation with a reduced existential prospect. Further links in the chain of reflection are ready to be included in pedagogy, by shifting towards responsibly caring about existence, in terms of its spirituality, intentionality, and the revitalisation of crucial points of human identity and development. Suffering, despair and death, when seen as an existential phenomenon of positive rather than pejorative meaning, restores the dramatically lost position of humanity without destroying the meaning of existence and our understanding of the world. It is not despair in the course of human life that causes the tragedy, but primarily the inability to see things, the lack of will to react to human life, which reveals a spiritual deadness that degrades the community. For this reason, an existentially focused education seems to represent a serious approach to a person in the context of their entire life. Tillich's diagnoses (1994, pp. 152-153) appear to be valid; they are stated as follows:

Twentieth-century man has lost a meaningful world and a 'self' which lives in meanings which lack a spiritual centre. ... But man still is aware of what he has lost or is continuously losing. He is still a man enough to experience his dehumanisation as despair. He does not know the way out but he tries to save his humanity by expressing the situation as without an 'exit'. He reacts with the courage of despair, the courage to take his despair upon himself and to resist the radical threat of nonbeing through the courage to be himself.

The dramatic struggle against the scale of human degradation is a rebellion against the existential loss of a person, who is filled with joy and pleasure, as well as despair and death - which are treated not as a threat but as a space for considering the depth of existence. The confession included in the last will of John Paul II calls for an attitude in which 'working through a loss' should trigger understanding, as the ultimate impulse to give meaning to life and open prospects for the appreciation of something that has been completed due to life, as well as due to death. Since even death, as a 'destination of 
despair' (Tischner, 2013, p. 181) can be treated as an optimistic vision, telling us that death, as we know it when it moves us, has the power to shake our conscience so that it becomes an opportunity for a dramatic transformation of one's own life. The experiencing of the ultimate changes the way we see our fate and the life of an individual. Thus, we are given a chance to develop a new dimension of caring about our own life.

Existential sensitivity, characterised by caring about others, opens a possible space for pedagogical activities; this creates a challenge for educational subjects, which stresses the importance of a serious approach to the fate of one's students, with the hope that they will live their lives in a meaningful way. Examining the existential challenges that centre around the issues of death and despair allows us to outline the main educational tasks related to the following, inter alia:

- organisation of supportive and helping actions, dedicated to people who are subjects of the educational situation and have been exposed to traumatic experiences (e.g. sickness, death, pain, parental divorce); and simultaneously, teaching students to be sensitive about mindfulness when having contact with others, which allows them to interpret the extreme state of a person, and to be a helpful companion in various situations;

- creating preventive and educational programmes that are designed to help people to work through the experience of despair, pain and death, through designing tasks of an existential nature for children and young people by using, inter alia, cultural texts;

- designing educational tasks (based on analysis and solving problems of an existential nature) intended to build the abilities of 'confronting' despair and pain in different life situations, through showing the existential worth of the unexpected, the 'gifts' received through being hurt, and the possibility of creating a peaceful relationship with life despite these experiences.

\section{References}

Andreoli, V. (2009). Zrozumieć cierpienie. Aby ból ustapit radości [Understand suffering. So pain can give in to joy]. Trans. M. Bielawski. Kraków: Homini.

Bosmans, P. (1991). Być człowiekiem [Be human]. Trans. F. Żołnowski. Warsaw: Wydawnictwo Salezjańskie.

Frankl, V. E. (1971). Homo patiens. Trans. R. Czernecki, J. Morawski. Warsaw: PAX. 
Frankl, V. E. (2010). Wola sensu. Założenia and zastosowanie logoterapii [Will to meaning. Foundations and Applications of Logotheraphy]. Trans. A. Wolnicka. Warsaw: Czarna Owca.

Frankl, V. E. (2014). Czlowiek w poszukiwaniu sensu [Man's search for meaning]. Trans. A. Wolnicka. Warsaw: Czarna Owca.

Gonet, K. (2002). Jak by to powiedzieć... Rozmowy z Krystianem Lupa [How to put it... Conversation with Krystian Lupa]. Kraków: Wydawnictwo Krakowskie.

Frąckowiak, T. (2007). O pedagogice nadziei. Fascynacje and asocjacje aksjologiczne [About pedagogy of hope. Axiological fascinations and associations]. Poznań: UAM.

Lupa, K. (1999). Rozmowa. Entretien avec Michel Archimbaud [Conversations. Entretien avec Michel Archimbaud], ed. J. Baillon. Kraków: Centre National du Theatre, Paris, C\&D.

Lupa, K. (2003a). Podgladania [Snoopings]. Warsaw: WAB.

Lupa, K. (2003b). Utopia 2. Penetracje [Utopia 2. Penetrations]. Kraków: Wydawnictwo Literackie.

Merton, T. (2005). Piękno pustyni [The Wisdom of the Desert]. Trans. K. Stankiewicz. Kraków: Salwador.

Szczepański, J. (1988). Sprawy ludzkie [Human issues]. Warsaw: Czytelnik.

Tischner, J. (2012). Filozofia dramatu [Philosophy of drama]. Kraków: Znak.

Tischner, J. (2013). O człowieku. Wybór pism filozoficznych [About a man. Selection of philosophical writings], ed. A. Bobko, M. Kozak. Wrocław: Zakład Narodowy im. Ossolińskich.

Tillich, P. (1994). Męstwo bycia [The Courage to Be]. Trans. H. Bednarek. Poznań: Rebis.

Tillich, P. (2004). Teologia systematyczna, t. II [Systematic Theology, Vol. II]. Trans. J. Marzęcki. Kęty: Antyk.

Twardowski, J. (1979). Poezje wybrane [Selected poems]. Warsaw: Ludowa Spółdzielnia Wydawnicza.

Twardowski, J. (1993). Wiersze [Poems]. Białystok: Łyk.

Walczak, P. (2007). Wychowanie jako spotkanie. Józefa Tischnera filozofia człowieka jako źródto inspiracji pedagogicznych [Education as meeting. Józef Tischner's philosophy of a man as a source of pedagogical inspiration]. Kraków: Impuls. 
